\title{
PEACEKEEPING FORCES, JURISDICTION AND IMMUNITY: A TRIBUTE TO GEORGE BARTON
}

\author{
Roger S Clark*
}

George Barton wrote his PhD thesis at Cambridge on "Jurisdiction over Visiting Forces". He published three spinoffs from the thesis in the British Yearbook of International Law. In all of these - each a tour de force in examining elusive and arcane State practice - he was at great pains to deny various supposed customary rules recognising immunity of foreign armed forces in the courts of a State in which they were visiting by consent. He worked in the United Nations Secretariat in New York just as the practice of United Nations peacekeeping began to develop. In this tribute, I try to imagine that he returned to the subject some 60 years later. Affecting, as best I can, the style of Dr Barton circa 1950, I offer some guesses as to how he might assess six decades of developments in law and practice in the multilateral context in which the United Nations, and especially the Secretariat and the Security Council, have been major actors.

George wrote his $\mathrm{PhD}$ thesis at Cambridge under the supervision of the leading international law scholar of his day, Hersch Lauterpacht. The title was "Jurisdiction over Visiting Forces". Among the many valuable lessons I received from George was one about the importance of the colon. He published three articles in the British Yearbook of International Law based on his work at Cambridge, each with the obligatory colon in the title. Each one, more importantly, was a tour de force of erudite scholarship, showing amazing facility not only with the usual British and European sources of material, but also with Egyptian and Brazilian case law and treaty instruments. ${ }^{1}$ I am pretty sure that I read only the second one of them, on immunity from criminal jurisdiction, as his student in international law in 1963. But I know it impressed me with what a complicated thing it is

* BA, LLD (Victoria University of Wellington), LLM, JSD (Columbia), Board of Governors Professor, Rutgers University School of Law, Camden, New Jersey. The author is grateful for comments on previous drafts made by Sir Ken Keith, Andrew Ladley, Kevin Riordan and James Stewart. Brian Johns provided invaluable research assistance. They are not to be blamed for the result.

1 GP Barton "Foreign Armed Forces: Immunity from Supervisory Jurisdiction" (1949) 26 BYIL 380; GP Barton "Foreign Armed Forces: Immunity from Criminal Jurisdiction" (1950) 27 BYIL 186; GP Barton "Foreign Armed Forces: Qualified Jurisdictional Immunity" (1954) 31 BYIL 341. 
trying to nail down State practice, especially when much of the relevant area is populated by bilateral and multilateral treaties. ${ }^{2}$ It was at about the same time that he introduced me to The Lotus, and its insight (again among many) that there can be concurrent jurisdiction. ${ }^{3}$ The hapless $\mathrm{M}$ Demons, master of the watch on The Lotus on the high seas when it ran into the Turkish collier, was potentially liable to prosecution both in Turkey (where he came ashore and where there were dead Turks) and in France (the flag State and State of nationality). Turkey had custody of him so, perforce, it had 'first dibs' on prosecution. What, however, if he had been immune from prosecution in Turkey? But I get a bit ahead of the story. ${ }^{4}$

In his thesis and articles, George was at pains to deny various supposed customary rules recognising immunity of foreign armed forces from prosecution in the courts of a State in which they were "visiting". ${ }^{5}$ Writing triumphantly in 1954 , after the emergence of the NATO Status of Forces Agreement (NATO SOFA) of 19 June $1951,{ }^{6}$ George declared: ${ }^{7}$

2 As George put it in GP Barton "Foreign Armed Forces: Immunity from Criminal Jurisdiction", ibid at 231:

Where a series of international agreements make uniform arrangements on a given subject, it is not easy to decide whether they consecrate by formal recognition a generally accepted principle of international law or whether they constitute a deviation therefrom ... The weight of evidence lies, it is submitted, against accepting those agreements which conferred on members of a visiting force absolute immunity from criminal prosecution in the local courts as fulfilling an obligation under international law on the part of the local state.

3 The Lotus (France v Turkey) (1927) PCIJ (series A) No 10 at 4. For some thoughts on The Lotus by another of George's students, see KJ Keith "The International Court of Justice and Criminal Justice" (2010) 59 ICLQ 895.

4 To get ahead of the answer: obviously France should have prosecuted.

5 GP Barton "Foreign Armed Forces: Immunity from Criminal Jurisdiction", above n 1, at 186:

The term 'visiting' when used to describe an armed force implies that this force has come to and sojourns in the territory of the local state with its consent and by its invitation. It is not unknown for such consent to be given reluctantly.

(George's wry sense of humour is apparent in the second sentence). The jumping-off point for much of George's discussion is Marshall CJ's opinion in The Schooner Exchange v McFaddon 11 US 116 (1812) at 135. He insisted that the dicta there about visiting forces pertained to immunity from supervisory jurisdiction, not immunity from criminal jurisdiction. For New Zealand law consistent with this, see s 15 of the Visiting Forces Act 2004 (proceedings of service tribunal of visiting force not called into question in a New Zealand court).

6 Agreement between the Parties to the North Atlantic Treaty regarding the Status of their Forces 199 UNTS 68 (opened for signature 19 June 1951, entered into force 23 August 1953) [NATO SOFA].

7 GP Barton "Foreign Armed Forces: Qualified Jurisdictional Immunity", above n 1, at 370. Is it too much to detect in this an early example of the tension present in George's work between the practitioner (including the international lawyer) and the academic? Was he a little scornful of the academic side, even while drawn to it for a significant part of his professional life? 
The examination of the available evidence would appear to support the conclusion that there is no basis for a supposed rule of international law recognising immunity from prosecution in local courts for members of a visiting force who commit offences either within the limits of their quarters, or while on duty, or against fellow servicemen or their property. The first two of these circumstances have the support of textbook writers over a period of a hundred years or more. There is now in existence a multilateral jurisdictional agreement [the NATO SOFA] which may be expected to record the highest common factor of agreement and which passes over in silence the traditional concept of conditional immunity in favour of a radically new system of priorities in the exercise of jurisdiction for certain offences. This modern departure from the theories of writers provides some evidence that those theories did not conform to international law as fully as their emphatic language seemed to indicate.

For George, there would normally be concurrent jurisdiction over visiting forces; the territorial State would have jurisdiction on the basis of that territoriality, and the sending State would have jurisdiction over the members of its forces in its military courts (perhaps in situ in the host country), or even in its civilian courts at home. Exactly how it all worked out was a matter of negotiation between the parties, either an advance negotiation by treaty before any specific matters arose, or ad hoc after the event. ${ }^{8}$ Such a treaty might, of course, grant complete or partial immunity from the courts of the host State, but that was not de rigeur. So you can see how he liked the NATO arrangement. It deals with "cases where the right to exercise jurisdiction is concurrent" (most cases for George), setting out rules on which State has primacy. ${ }^{9}$ The military authorities of the sending State are to have the primary right to exercise jurisdiction over a member of a force or of a civilian component in relation to:

(1) offences solely against the property or security of that State, or offences solely against the person or property of another member of the force or civilian component of that State or of a dependent; and

(2) offences arising out of any act or omission done in the performance of official duty. In respect of any other offence, the authorities of the receiving State have the primary right to exercise jurisdiction.

Where the State having the primary right decides not to exercise jurisdiction, it is to notify the authorities of the other State. The latter, presumably, will decide whether - or not - to exercise its 'secondary' right to prosecute. The authorities of the State having the primary right are to give

8 See GP Barton "Foreign Armed Forces: Immunity from Criminal Jurisdiction", above n 1, at 234; GP Barton "Foreign Armed Forces: Qualified Jurisdictional Immunity", above n 1, at 365. George was not completely explicit about his methodology. I think he accepted that treaties can be a 'source' of customary law, but did not regard the existing practice as consistent enough (or sufficiently accompanied by opinio juris?) to constitute the norm. For similar non-explicit treatment of treaties-as-custom, see The Lotus, above n 3, at 27 .

9 NATO SOFA, above n 6, art VII(3). 
sympathetic consideration to a request for a waiver of that right in cases where the other State considers such a waiver to be of particular importance. The solution, it will be noted, is all in jurisdictional terms; immunity (by name at least) is not on the table.

After Cambridge, no doubt upon Lauterpacht's recommendation, George spent from 1950 to 1952 in the Human Rights Division of the United Nations Secretariat in New York. ${ }^{10}$ Had he remained another 60 years in New York, he might have written something along the following lines: 11

Immunity was to rear its ugly head again with the emergence of United Nations peacekeeping forces, present with the consent of the host State. There were immunities both for military contingents and the accompanying (and necessary) civilian bureaucracy. There might have been some expectations on the part of host States that disciplinary action, including action of the criminal kind, would be exercised somewhere else. Jurisdiction being concurrent, immunity in a host State did not mean there would be immunity elsewhere, resulting in impunity. But it turned out that jurisdiction on the part of the sending State (or of the State of nationality of an international civil servant) was not as secure a matter in all parts of the globe as the NATO negotiators were able to assume it was among themselves. What can be done?

What follows is thus a response to the narrative I have just attributed to George. Part I, "Immunity Resurgent", examines the problem. Part II, "A Convention on Jurisdiction?" examines part of a potential solution. Part III, "A New United Nations Model Memorandum of Understanding", examines another part. A brief conclusion, in which I try to echo the style of George's British Yearbook of International Law pieces, attributes some more hypothetical thoughts to George.

10 He attached me to his formidable network there in 1967 when I went as a graduate student to New York. He still had a strong following amongst both the professional staff and the secretarial and filing people - he was ever courteous to both groups. On his fellow Cambridge/Lauterpacht product and lifelong friend, Kamal Das, see RS Clark "Human Rights Strategies of the 1960s Within the United Nations: A Tribute to the Late Kamleshwar Das" (1999) 21 HRQ 308.

11 Hypothetical thoughts fondly attributed to GP Barton. I am not sure how hypothetical the thoughts are. George in fact returned to some of the visiting force issues in contributions he made (along with other notables like Rosalyn Higgins and Louis B Sohn) in DW Bowett United Nations Forces: A Legal Study (Stevens, London, 1964). No attribution is made of the particular contribution of individual authors but I am convinced from its content and style that ch 13 on "Agreements with 'Host' States" is largely George's, and it is consistent with what I attribute to him in the text. 


\section{IMMUNITY RESURGENT ${ }^{12}$}

While George was researching at Cambridge, the first United Nations peacekeeping operation, the United Nations Truce Supervision Organisation (UNTSO), was created, the initial of many vain United Nations endeavours to 'fix' the Middle East. "Peacekeeping" is not a term that appears in the Charter. The definitive United Nations in-house study of the concept concedes that "[t]he concept of peacekeeping evolved soon after the United Nations was founded, born of necessity as a largely improvised response to the times." ${ }^{13}$ An initial group of 36 peace observers was put into place in June of 1948 and subsequently increased to $93 .{ }^{14}$ The parties apparently accepted that the Convention on the Privileges and Immunities of the United Nations (CPIUN) applied to the observers. ${ }^{15}$ The practical effect of this appears to have been that any members of the United Nations Secretariat involved would, as "officials of the United Nations", be "immune from legal process in respect of words spoken or written and all acts performed by them in their official capacity". ${ }^{16}$ The military observers themselves had a similar entitlement by being classified as

12 Issues involving visiting forces are only one example of the current ferment on immunities. See for example B Stephens "The Modern Law of Foreign Official Immunity" (2011) 79 Fordham LRev 2669 (tort litigation in US); Arrest Warrant (Democratic Republic of Congo v Belgium) [2002] ICJ Rep 121 (immunity of Foreign Minister from criminal prosecution); Jurisdictional Immunities of the State (Germany $v$ Italy) (3 February 2012) (ICJ No 143) (violation of immunity through cases filed in Italian courts arising out of World War II); and note the International Law Commission's ongoing project on "Immunity of State officials from foreign criminal jurisdiction". (For an update see International Law Commission "Summary: Immunity of State officials from foreign criminal jurisdiction" (10 October 2011) < untreaty.un.org>.)

13 United Nations Department of Public Information The Blue Helmets: A Review of United Nations Peacekeeping (3rd ed, United Nations Department of Public Information, New York, 1996) at 3. On the subject in general, see M Odello and R Piotrowicz (eds) International Military Missions and International Law (Martinus Nijhoff Publishers, Leiden, 2011).

14 United Nations Department of Public Information The Blue Helmets: A Review of United Nations Peacekeeping, ibid at 19.

15 Ibid. Convention on the Privileges and Immunities of the United Nations 1 UNTS 15 (opened for signature 13 February 1946, entered into force 17 September 1946). See also 90 UNTS 327 (corrigendum). The Convention spells out in more detail the generalities on privileges and immunities contained in arts 104 and 105 of the United Nations Charter. One hundred and fifty seven of the organisation's 193 States had become parties to the Convention on the Privileges and Immunities of the United Nations by late 2011. The organisation optimistically treats its principles, at least, as customary law for the others. There are, of course, analogies between State immunities and organisation immunities. The high ranking international organisation functionaries tend to have (absolute) immunities similar to those of diplomatic agents. The Convention on the Privileges and Immunities of the United Nations, s 19 afforded the Secretary-General and all Assistant Secretaries-General and their families "the privileges and immunities, exemptions and facilities accorded to diplomatic envoys, in accordance with international law." This became relevant in later usage, below at fns 35-39. The lower ranks receive something closer to those of consular officials, namely functional immunity. See Convention on the Privileges and Immunities of the United Nations, s 18. See also United Nations Department of Public Information The Blue Helmets: A Review of United Nations Peace-keeping, above n 13, at 19.

16 At s 18 . 
"experts on mission" for the organisation. The relevant wording of the CPIUN was a little different, but the practical effect was the same. They were to be accorded: ${ }^{17}$

... in respect of words spoken or written or acts done by them in the course of the performance of their mission, immunity from legal process of every kind. This immunity from legal process shall continue to be accorded notwithstanding that the persons concerned are no longer employed on missions for the United Nations.

Thus was born a new context for immunity issues in respect of temporary sojourners with military connections. The visitors came under the auspices not of a State, but of an international organisation, albeit organised in national contingents but with some common leadership. And the accompanying civilian part, typically international civil servants (on either permanent or temporary contracts), was significant.

Following the 1956 invasion of Egypt by Israel, France and the United Kingdom, a more sophisticated enterprise was created, the First United Nations Emergency Force (UNEF I). ${ }^{18}$ A feature of this was the first United Nations Status of Forces Agreement (UN SOFA), negotiated with Egypt, where the UNEF I was stationed: "[Members of the UNEF I] shall be subject to the exclusive jurisdiction of their respective national States in respect of any criminal offences which they might commit in Egypt." ${ }^{19}$ Bowett rationalised this "divergence" from other practice thus: ${ }^{20}$

... a United Nations Force will invariably be completely independent of and rarely, if ever, allied to the local forces. For this very reason the considerations that apply to forces stationed indefinitely in the territory of an ally, training and generally co-operating with the local forces, and becoming to a not inconsiderable degree assimilated in the society in which they are stationed, without being immediately involved in actual operations, lose much of their cogency in the case of a United Nations Force as arguments in favour of denying total immunity.

On the other hand, members of the Secretariat and the Commander received immunities consistent with the CPIUN. ${ }^{21}$ This agreement "provided a pattern", ${ }^{22}$ followed for subsequent

17 At s 22(b). Note the continuing immunity even after the mission was over.

18 United Nations Department of Public Information The Blue Helmets: A Review of United Nations Peacekeeping, above n 13, at 35.

19 Ibid at 42; Exchange of letters constituting an agreement between the United Nations and the Government of Egypt concerning the Status of the United Nations Emergency Force in Egypt 260 UNTS 61 (8 February 1957), art 11. None of George's examples of practice included treaties involving international organisations, a phenomenon that became a feature of international practice with the United Nations.

20 DW Bowett United Nations Forces: A Legal Study, above n 11, at 438. In the following paragraph, Bowett notes a comment by the Secretary-General that the United Nations Emergency Force provision on exclusive jurisdiction was "essential to the successful recruitment ... of national contingents."

21 Convention on the Privileges and Immunities of the United Nations, above n 15, arts 24 and 25. 
peacekeeping operations to this day. ${ }^{23}$ Indeed, in 1990, as part of a "comprehensive review of the whole question of peace-keeping operations in all their aspects", the Secretary-General issued a Model status of forces agreement for peace-keeping operations. ${ }^{24}$ Its provisions built on both the CPIUN and the 1956 UN SOFA.

The 1990 Model status of forces agreement for peace-keeping operations proceeded on the basis that contingents will be coming from various countries and that the operation will be headed (on the civilian side) by a Special Representative of the Secretary-General (SRSG) and (on the military side) by a Commander. Early in the document is a statement that the operation and its members "shall refrain from any action or activity incompatible with the impartial and international nature of their duties or inconsistent with the present arrangements." 25 Moreover, all involved are to "respect all local laws and regulations," and the Special Representative/Commander ${ }^{26}$ is to "take all

22 United Nations Department of Public Information The Blue Helmets: A Review of United Nations Peacekeeping, above $\mathrm{n} 13$, at 42 .

23 The nature of the enterprise evolved. M Bothe and T Dörschel "The UN Peacekeeping Experience" in D Fleck (ed) The Handbook of the Law of Visiting Forces (Oxford University Press, Oxford, 2001) 487 at 489 (footnotes omitted), describe the "various functions" of a modern operation thus:

These are traditionally observation duties, the establishment of buffer zones and maintenance of law and order in a particular area. These functions have been expanded and include demobilisation and reintegration of former combatants, local disarmament, humanitarian assistance, human rights observation, assistance in the re-establishment of a new system of government, in particular in view of elections, and, last not least, mine clearance or assistance therein.In the present century, peacekeeping operations are increasingly being tasked with "peace enforcement", a development that does not garner universal praise.

See also J Sloan The Militarisation of Peacekeeping in the Twenty-First Century (Hart Publishing, Oxford, 2011).

24 Model status of forces agreement for peace-keeping operations A/45/594 (1990) [Model SOFA agreement]. "The model is intended to serve as a basis for the drafting of individual agreements to be concluded between the United Nations and countries on whose territory peace-keeping operations are deployed." J Sloan The Militarisation of Peacekeeping in the Twenty-First Century, ibid at 1 . The SOFA with the host country is normally accompanied by another agreement between the United Nations and the troop-contributing countries. See below at fns 88-103.

25 At art 6.

26 In using "Special Representative/Commander", I follow the convention found in the United Nations documents. 
appropriate measures to ensure the observance of these obligations". ${ }^{27}$ In addition, the SecretaryGeneral is obligated to: ${ }^{28}$

... obtain assurances from Governments of participating States that they will be prepared to exercise jurisdiction with respect to crimes or offences which may be committed by members of their national contingents serving with the peace-keeping operation.

There are detailed provisions on privileges and immunities. The Special Representative, the Commander and "such high-ranking members of the Special Representative/Commander's staff as may be agreed upon with the Government" have the privileges accorded to diplomatic envoys. ${ }^{29}$ Members of the United Nations Secretariat with the civilian component "remain officials of the United Nations" and are thus entitled to immunity "in respect of words spoken or written and all acts performed by them in their official capacity." 30 Military observers, United Nations civilian police and civilian personnel other than United Nations officials whose names are appropriately notified to the government of the receiving State, "shall be considered as experts on mission within the meaning of [s 22] of the Convention [on Privileges and Immunities]". ${ }^{31}$ They thus also have functional immunity. ${ }^{32}$ Finally, the Model status of forces agreement for peace-keeping operations records that military personnel of national contingents "shall have the privileges and immunities specifically provided for in the present agreement." 33 This has to be read along with a later provision in the Model status of forces agreement for peace-keeping operations (derived from the UNEF I prototype) under which: ${ }^{34}$

27 At art 6 .

28 At art 48. For some years, an appropriate clause was normally inserted in the State's agreement to provide personnel; that practice fell into desuetude, but has now been re-established. See below n 104.

29 At art 24. Compare with $n 15$ above.

30 At art 25

31 At art 26 .

32 The various specific provisions on functional immunity are reinforced by art 46 which provides:

All members of the United Nations peace-keeping operation including locally recruited personnel shall be immune from legal process in respect of words spoken or written and all acts performed by them in their official capacity. Such immunity shall continue even after they cease to be members of or employed by the United Nations peace-keeping operation and after the expiration of the other provisions of the present Agreement.

Article 46 is not entirely redundant. It extends immunity not specifically granted elsewhere to local recruits and makes it clear that the immunity is not just personal immunity while the employment lasts - it is subject-matter immunity, good for all time.

33 At art 27.

34 At art 47(b). SOFAs often confirm that the adjudicative powers of the visiting force may be exercised in the host country. See for example: the NATO SOFA, above n 6, at art VII. I could find no specific language to 
... military members of the military component of the United Nations peace-keeping operation shall be subject to the exclusive jurisdiction of their respective participating States in respect of any criminal offences which may be committed by them.

This "jurisdictional" provision goes beyond functional immunity since it operates as an absolute bar to personal jurisdiction and there is no room for arguing about whether the activity in question took place in the course of official duties or not. Any rights or obligations with respect to prosecution of military lie with the sending State. ${ }^{35}$

The situation is a little more complicated in respect of the criminal responsibility of civilian operatives because of the presence of functional immunity only and the need to determine when that immunity applies. Article 47 of the Model status of forces agreement for peace-keeping operations states that, where the Government of the host State considers that a member of the operation has committed a criminal offence, it is to inform the Special Representative/Commander and present him with any available evidence. If the accused is a member of the civilian component or a civilian member of the military component, ${ }^{36}$ the "Special Representative/Commander shall conduct any necessary supplementary inquiry and then agree with the Government whether or not criminal proceedings should be instituted". ${ }^{37}$ The power to "agree" (or presumably to disagree) must be an

this effect in the Model SOFA agreement. The power is probably implicit: see Prince Zeid Ra'ad Zeid AlHussein's comment in A comprehensive strategy to eliminate future sexual exploitation and abuse in United Nations peacekeeping operations annexed to Letter dated 24 March 2005 from the Secretary-General to the President of the General Assembly A/59/710 (2005) at 16.

35 Vienna Convention on Diplomatic Relations 500 UNTS 95 (opened for signature 18 April 1961, entered into force 24 April 1964), art 32, expressly provides that a sending State may waive the immunity of its diplomatic agents. Although the Model SOFA agreement has no waiver provision, such a power may perhaps be implied, although DW Bowett United Nations Forces: A Legal Study, above n 11, at 441, doubts the power to do so. Some bilateral SOFAs achieve the same result as the Model SOFA agreement - denial of host State jurisdiction - by assimilating personnel (military and civilian) to administrative and technical staff of a diplomatic mission under the Vienna Convention on Diplomatic Relations, and thus entitled to absolute immunity in criminal proceedings. One such agreement, between the United States and Colombia, also contains this: "The appropriate authorities of the United States shall give sympathetic consideration to a request for waiver of immunity in cases that the authorities of Colombia consider to be of particular importance." Supplemental Agreement for Cooperation and Technical Assistance in Defense and Security United States-Columbia (30 October 2009), art VIII(5); Note No 159/2006 from the Australian Embassy in Dili to Ministry of Foreign Affairs and Cooperation of the Democratic Republic of Timor-Leste regarding The Arrangements concerning the Status of Visiting Personnel in Timor-Leste (26 May 2006), Annex A, affords "Visiting Personnel" (everyone involved) a status equivalent to that accorded administrative and technical staff under the Vienna Convention, but is silent on waiver.

36 High officials will have absolute immunity, above n 29; military members will not be subject to the local jurisdiction, above $\mathrm{n} 34$ and 35.

37 Model SOFA agreement, above n 24, art 47(a). If there is no agreement on proceedings, the Model SOFA agreement's dispute settlement provisions come into play. 
amalgam of a power to waive immunity, ${ }^{38}$ and an (implied?) power to determine whether the activities in question took place in the course of official duties. ${ }^{39}$

Trial is one thing; enforcement jurisdiction is another. The Model status of forces agreement for peace-keeping operations obligates the Special Representative to "take all appropriate measures to ensure the maintenance of discipline and good order among members of the United Nations peacekeeping operation". ${ }^{40}$ To this end, the areas occupied by the mission are to be policed. Elsewhere in the land, policing personnel are to be employed subject to arrangements with the government and in liaison with it. ${ }^{41}$ United Nations military police have powers of arrest over the military members of the operation. Military personnel placed under arrest outside their own contingent's areas are to be transferred to their contingent Commander for appropriate disciplinary action. ${ }^{42}$ The host government may arrest members of the United Nations operation when so requested by the Special Representative/Commander or "[w]hen such a member ... is apprehended in the commission or attempted commission of a criminal offence." 43 A person so apprehended "shall be delivered immediately, together with any weapons or other item seized, to the nearest appropriate representative of the United Nations". ${ }^{44}$ Arrest by the host State is thus permissible, but only when the member is apprehended in flagrante. And it is not accompanied by a right to try the accused. ${ }^{45}$

In 2004, revelations of outrageous sexual abuse by peacekeeping personnel in the Democratic Republic of the Congo led the Secretary-General to address the abuse problem. ${ }^{46} \mathrm{He}$ asked His

38 Convention on the Privileges and Immunities of the United Nations, above n 15, s 20 provides that:

Privileges and immunities are granted to officials in the interests of the United Nations and not for the benefit of the individuals themselves. The Secretary-General shall have the right and the duty to waive the immunity of any official in any case where, in his opinion, the immunity would impede the course of justice and can be waived without prejudice to the interest of the United Nations.

Similar language appears in s 22 in respect of experts on mission.

39 Model SOFA agreement, above n 24, art 49 specifically empowers the Special Representative/Commander to decide definitively for the purposes of a civil proceeding whether or not the proceeding is related to official duties, but there is nothing as explicit in the Model SOFA agreement concerning criminal proceedings. It must be implied surely, and the United Nations apparently proceeds on that basis.

40 Model SOFA agreement, above n 24, art 40.

41 Ibid.

42 At art 41

43 At art 42 .

44 Ibid.

45 On this "division" of jurisdiction, see below at fns 70-73.

46 See generally EF Defeis "UN Peacekeepers and Sexual Abuse and Exploitation: An End to Impunity" (2008) 7 WUGSLR 185. Andrew Ladley gives a good account of the problem in A Ladley "Peacekeeper 
Royal Highness Prince Zeid Ra'ad Zeid Al-Hussein, Permanent Representative of Jordan to the United Nations, to assist him. In particular, when the General Assembly's Special Committee on Peacekeeping Operations requested a comprehensive report, ${ }^{47}$ the Secretary-General asked Prince Zeid to undertake its preparation. Prince Zeid's report appeared in March of 2005 (the Zeid Report). ${ }^{48}$ While it is addressed specifically to questions of sexual exploitation, the Zeid Report is of great significance for its discussion of jurisdictional and immunity issues in general.

Appropriately, much of the Zeid Report is devoted to improving existing rules on standards of conduct for those involved in peacekeeping, to organisational, managerial and command responsibility and to individual disciplinary and financial accountability. But there are also

Abuse, Immunity and Impunity: The Need for Effective Criminal and Civil Accountability in International Peace Operations" (2005) 1 Politics \& Ethics Review 81 at 82-83. Ladley comments at 84:

The interplay between state-representative diplomatic immunity and the immunities of visiting forces under SOFAs illustrates why and how the complexities have arisen in relation to peace operations. 'Diplomatic' immunities were never intended to cover tens of thousands of 'representatives/employees' in a single deployment. SOFAs were intended to cover military personnel, not all civilians whether or not connected to the force. The legal framework is thus stretched well beyond protecting officials and employees working for the UN, to cover operations involving tens of thousands of 'UN peacekeepers'. It does not work very well.

Ladley also reminds us that it is not only in peacekeeping operations under United Nations auspices that immunity issues arise. He mentions the SOFA entered into for the Regional Assistance Mission in the Solomon Islands. The Solomon Islands ceded jurisdiction over police and civilian members of the mission only if the sending country could prosecute offences in its own courts. The New Zealand Parliament responded in 2004 with provisions now in the Policing Act 2008. Section 87 of that Act confers jurisdiction in the New Zealand courts over police or other persons who are outside of New Zealand as part of an "overseas operation" as defined in the Act. See also Crimes (Overseas) Amendment Act 2003 (Australia). Ladley notes, at 87, that "Comparable legislation appears to be extremely rare in the rest of the international community." A thoughtful host State with bargaining power should find the Solomons precedent attractive.

47 Report of the Special Committee on Peacekeeping Operations and its Working Group A/59/19/Rev1 (2005).

48 A comprehensive strategy to eliminate future sexual exploitation, above $\mathrm{n} 34$, at 1 . The Secretary-General commented that:

[T]he revelations in 2004 of sexual exploitation and abuse by a significant number of United Nations peacekeeping personnel in the Democratic Republic of the Congo have done great harm to the name of peacekeeping. Such abhorrent acts are a violation of the fundamental duty of care that all United Nations peacekeeping personnel owe to the local population that they are sent to serve.

This report is an excellent source of existing law and practice. There is also a good survey of the issues in M Odello "Tackling Criminal Acts in Peacekeeping Operations: The Accountability of Peacekeepers" (2010) 15 JCSL 347. The public relations disaster that this all presented for the United Nations refuses to go away. See Paul Hond "The Long Night: Tackling the Scourge of Sex Trafficking from the Big Screen to the Big Street" Colombia Magazine (New York, Fall 2011) (describing release of the brilliant film, The Whistleblower (2010), containing depressing material on the involvement of peacekeepers in sex trafficking in Bosnia). 
significant discussions of matters of investigation and of criminal accountability. The Zeid Report notes that one of the difficulties of dealing with the problem of accountability as a whole is that an operation may have several categories of personnel to whom different rules may apply. In particular, contributing countries are responsible for the conduct and discipline of their troops, but the Secretary-General may have control over civilian police, military observers, United Nations volunteers, consultants and individual contractors. All of these are likely to have immunities of some kind, subject to the Secretary-General's (or his representative's) power to waive those immunities.

So far as troops are concerned, the fundamental problem is that the United Nations does not have its own criminal courts, or even a body of written criminal norms. The Zeid Report recommended the establishment by the organisation of a professional investigative mechanism to deal with serious cases of misconduct. Moreover, an expert in military law, preferably a prosecutor from the troop-contributing country concerned, should participate in any investigation of members of its contingent. ${ }^{49}$ Furthermore: ${ }^{50}$

[T]roop-contributing countries should hold on-site courts martial, since that would facilitate access to witnesses and evidence in the peacekeeping area. Troop-contributing countries whose legislation does not permit on-site courts martial should consider reforming their legislation.

He also pointed out that, while the Model status of forces agreement for peace-keeping operations assumes that the Secretary-General will obtain assurances from troop-contributing countries that they will exercise criminal jurisdiction over their troops in return for host State immunity, such assurances were no longer being required: ${ }^{51}$

Such clauses should once again be inserted into the model memorandum of understanding [between the United Nations and the troop-contributor] to ensure that troop-contributing countries have a legal obligation to consider for prosecution acts of sexual exploitation and abuse committed by military members of peacekeeping missions that constituted crimes under the laws of the troop-contributing country or the host State.

One does not want to underestimate the practical problems in fronting up the witnesses and prosecuting, whether in the host State or in the sending State, but there are circumstances where the effort must be made!

49 A comprehensive strategy to eliminate future sexual exploitation, ibid at 4.

50 At 4-5. For an earlier proposal to this effect, see DW Bowett United Nations Forces: A Legal Study, above $\mathrm{n} 11$, at 439. Note that the host State might also find it necessary to adopt legislation empowering courtsmartial on their territory. See for example New Zealand's Visiting Forces Act 2004, s 8(1). But see s 9(1) (no power to impose or carry out sentence of death in New Zealand or do any act that would constitute an offence against the Crimes of Torture Act 1989).

51 At 6. See also below n 105. 
In respect of the criminal accountability of United Nations staff and experts on mission, the Zeid Report argued that the founders of the United Nations had not intended that privileges and immunities should constitute a complete shield from prosecution. Immunity should, indeed, be waived where appropriate. However, the absence of a functioning judicial system in some jurisdictions "means that it is not feasible to waive immunity in those jurisdictions." 52 Consequently, the United Nations having no criminal jurisdiction of its own, the prosecution of staff or experts: ${ }^{53}$

... depends on whether the State of nationality of the suspect has conferred extraterritorial jurisdiction on its courts to take such action and whether it can, in the circumstances of the case, effectively take such action. But this would tend to be the exception rather than the rule.

The Zeid Report recommended that the Secretary-General appoint a group of experts: ${ }^{54}$

... to advise him whether it would be feasible to draft an international instrument or use other means to ensure that United Nations personnel are subject to criminal prosecution for defined crimes of sexual exploitation and abuse.

\section{A CONVENTION ON JURISDICTION?}

Having considered the Zeid Report, the Special Committee on Peacekeeping Operations passed on a number of recommendations. ${ }^{55}$ These included Prince Zeid's recommendation that the Secretary-General should appoint a group of legal experts to prepare a report which would: ${ }^{56}$

... provide advice on the best way to proceed so as to ensure that the original intent of the Charter of the

United Nations could be achieved, namely that United Nations staff and experts on mission would never

be effectively exempt from the consequences of criminal acts committed at their duty station, nor

unjustly penalised, in accordance with due process.

It bears emphasis, as this language indicates, that the Committee found it possible to address only the question of jurisdiction over civilian personnel. It notes that "[t]he recommendations adopted by the Committee are without prejudice to the right of troop-contributing countries to

52 Ibid. I assume that "functioning" includes "functioning fairly".

53 Ibid.

54 Ibid.

55 Report of the Special Committee on Peacekeeping Operations and its Working Group, above n 47. Part Two of the Report (from 31 onwards), contains the discussion and recommendations concerning sexual exploitation and abuse and on criminal jurisdiction; the earlier part deals mainly with structural and management issues concerning peacekeeping operations.

56 At 37, endorsed by the General Assembly in Comprehensive review of a strategy to eliminate future sexual exploitation and abuse in United Nations peacekeeping operations GA Res 59/300, A/RES/59/300 (2005). 
exercise exclusive jurisdiction over their own contingents." ${ }^{57}$ Exercise of jurisdiction by troopcontributors would be addressed later another way. ${ }^{58}$

The resulting major recommendation from the legal experts' report, a surprising one to many, was that priority should be given to facilitating the exercise of jurisdiction by the host State. ${ }^{59}$ The legal experts (the Group) were emphatic that it should not be assumed that the host State is unable to exercise jurisdiction merely because a peacekeeping operation is carried out in a post-conflict area. If the host State is unable, even with United Nations assistance, to carry out all aspects of criminal jurisdiction, then there would be a need to rely on other States to do so. To provide a sound legal basis for other States to act, the Group recommended the development of a new convention to address jurisdiction and related issues. It attached a first draft of such a convention to its report. ${ }^{60}$

The Group outlined four main (and rather persuasive) arguments supporting its recommendation to emphasise host State jurisdiction: ${ }^{61}$

(1) The host State is the State on whose territory the crime was committed and there is little doubt that it may establish jurisdiction over conduct within its territory. This is regardless

57 Report of the Special Committee on Peacekeeping Operations and its Working Group, above n 47, at 31. The report does not record the discussion leading to this comment, but the gravitational pull of exemption from local jurisdiction for the military is evident. Indeed, the Special Committee also commented (at 14) that:

[W] hen civilian police, including civilian police deployed in formed police units and corrections personnel, are assigned executive tasks in which they directly implement law and order functions, they may be required to use enforcement measures in accordance with their mandates and rules of engagement. The Special Committee continues to believe that the tasks of such personnel require adaptation of the current rules governing their legal status, by assigning them immunities equivalent to those of armed military personnel, bearing in mind the need for accountability.

58 See below in this article in Part III, at fns 88-103.

59 Report of the Group of Legal Experts on ensuring the accountability of United Nations staff and experts on mission with respect to criminal acts committed in peacekeeping operations, annex to Ensuring the accountability of United Nations staff and experts on mission with respect to criminal acts committed in peacekeeping operations, Note by the Secretary-General A/60/980 (2006). The experts (the Group) came from Sri Lanka, Russian Federation, France, Australia and Singapore.

60 The Group discussed whether General Assembly or Security Council action alone might be adequate for the task. It concluded that a convention was more likely to achieve a sound basis for jurisdiction, notwithstanding that it would take time to negotiate, adopt and bring into force, and that it would apply only to those States that became parties.

61 Report of the Group of Legal Experts, above n 59, at 10-11. The Group noted that "some of these considerations are similar to those that have been cited in the Zeid report in support of its recommendation to hold on-site courts martial for members of military contingents" (citations omitted). See above n 50. 
of the identity of the alleged offender or of the victim, or whether another State can exercise jurisdiction over the same conduct;

(2) The host State is likely to be the place where most of the witnesses and evidence are located. Holding criminal trials in the host State will therefore avoid the cost, delays and inconvenience of witnesses having to travel overseas or of evidence having to be transmitted abroad;

(3) Holding an alleged offender criminally accountable in the host State flows from the obligation of United Nations peacekeeping personnel to respect all local laws and regulations as a corollary to their enjoyment of privileges and immunities in the host State; and

(4) Holding trials in the host State will give the local population a greater sense of justice being done and being seen to be done. This is important in demonstrating the commitment of the United Nations to the rule of law.

In order to make its host State emphasis work, the Group underscored the importance of capacity-building. It noted that many peacekeeping operations include a rule of lawcomponent involving the establishment or re-establishment of investigatory, prosecutorial or custodial institutions. "Such capacity-building", the Group suggested, "may enable the host State to exercise jurisdiction over all persons, including peacekeeping personnel, in accordance with international standards for human rights and due process." 62 The Group was anxious to avoid the suggestion that it was advocating higher standards for peacekeepers than for the local population. "In order to avoid any perception of double standards," it insisted, "capacity-building should focus on reviving the host State's legal system to deal with all persons, not just peacekeeping personnel." ${ }^{63}$ The Group may well have been too sanguine about the degree to which capacity-building can improve the current situation of impunity. Indeed, the Group conceded that "full capacity-building of the legal system can only be achieved long-term." 64 Accordingly, consideration could be given to: ${ }^{65}$

... whether reviving part of the host State's legal system (for example, in a particular region or only in relation to serious crimes against the person) is all that is needed in the short term to deal satisfactorily with peacekeeping personnel who commit serious crimes.

62 At 13. Obviously, sending States would not countenance unfair trials of their personnel on the theory that such trials were part of a learning exercise in the host State.

63 At $13 \mathrm{fn} 12$.

64 At 13.

65 Ibid. 
In some circumstances, the Group suggested, it might even be possible to create hybrid tribunals based on the models of the Special Court for Sierra Leone, the Extraordinary Chambers in the Courts of Cambodia, or the Special Panels for Serious Crimes established by the United Nations Transitional Administration in East Timor to try serious criminal offences in Timor-Leste. ${ }^{66}$ While the primary objective of those tribunals was to deal with international crimes, jurisdiction over such crimes was not a "prerequisite" for the establishment of hybrid tribunals. ${ }^{67}$

In principle ... hybrid tribunals can be established to deal exclusively with domestic crimes, including those committed by peacekeeping personnel, which do not arise to the level of international crimes.

The Group did not appear to regard widespread use of such a solution as likely. Nor did it regard the creation of a new international court to consider such cases, or an expansion of the existing jurisdiction of the International Criminal Court, as capable of achieving political consensus. ${ }^{68}$

More intriguing were the Group's suggestions about what it called "shared exercise of jurisdiction by the host State and other States." 69 This portion of the report is worth reproducing in full: ${ }^{70}$

40. There will be situations where the host State's legal system is unable to exercise criminal jurisdiction to a satisfactory level in the short term, with or without international assistance or capacitybuilding. Jurisdiction, however, is not an indivisible concept. It encompasses various activities ranging from investigations to adjudication to the detention of persons. Two or more States can be involved in exercising different but mutually supportive aspects of criminal jurisdiction consistent with the underlying principle that the greater the capacity of a host State to exercise criminal jurisdiction, the smaller the part which needs to be played by other States.

41. For example, the host State's authorities may be able to carry out the investigation and prosecution of offenders satisfactorily but its custodial institutions may be inadequate for imprisonment.

66 See generally ES Podgor and RS Clark Understanding International Criminal Law (2nd ed, Lexis Nexis, Newark, 2008) at 218-228.

67 Report of the Group of Legal Experts, above n 59, at 12.

68 Ibid at 19-21. A small subset of the kinds of crime in question might fit the category of war crimes or even crimes against humanity, but most of the depredations by peacekeepers - murder, rapes and other assaults would fail to meet the contextual threshold for such 'international' crimes. The Group concluded that "there are conceptual and practical difficulties" in creating an international organ for the purpose (at 21). On prosecution of peacekeepers for 'international' crimes, including by the International Criminal Court, see GJ Knoops The Prosecution and Defense of Peacekeepers under International Law (Martinus Nijhoff, Leiden, 2004); M O'Brien "The Ascension of Blue Beret Accountability: International Criminal Court Command and Superior Responsibility in Peace Operations" (2010) 15 JCSL 533.

69 Report of the Group of Legal Experts, above n 59, at 13.

70 Ibid (emphasis added, citations omitted). A footnote (n 13) adds that the shared jurisdiction "may be supported by a treaty or ad hoc arrangements between the States involved." 
In such cases, the host State investigates and prosecutes the person, but on conviction, he or she is returned to the State of nationality to serve the sentence of imprisonment under appropriate arrangements for the transfer of prisoners.

42. If, on the other hand, the host State's judicial system is not functioning to a satisfactory level and another State has to conduct the trial, it may still be possible for the host State's investigatory authorities to investigate the alleged crime, with or without assistance.

The concept of the "divisibility" of jurisdiction is an important one that I have begun to explore elsewhere. ${ }^{71}$ I have suggested that there is considerable explanatory value in the distinction drawn by the current Restatement of the Foreign Relations Law of the United States between 'prescriptive', 'adjudicative' and 'enforcement' jurisdiction which may be allocated, especially by treaty, among different actors. Jurisdiction to prescribe is the power of a State to make its substantive law applicable to particular activities; jurisdiction to adjudicate is the power to subject persons to its courts or administrative tribunals; jurisdiction to enforce is the power to compel compliance especially through executive, administrative, police or other non-judicial action. ${ }^{72}$ The Group's admonition that jurisdiction is not "an indivisible concept" underscores the basis in sound doctrinal theory for splitting up the incidents of sovereignty, especially by means of treaty arrangements. ${ }^{73}$ Aside from immunities, the host State, as the territorial sovereign, will have jurisdiction to prescribe, to adjudicate, and to enforce in respect of what happens on its territory. Prescriptive jurisdiction will be possessed concurrently with the State of nationality and perhaps other States. Absent consent of the host State, the sending State could not exercise any enforcement or adjudicative jurisdiction on the territory of the host State. A host State could, however, agree to the presence of investigators or prosecutors from the State of nationality on its territory, or it could agree to provide them with appropriate material that the host State itself has collected. It could even

71 RS Clark "Some Aspects of the Concept of International Criminal Law: Suppression Conventions, Jurisdiction, Submarine Cables and The Lotus" (2011) 22 CLF 519.

72 American Law Institute, Restatement of the Law, Third, Foreign Relations Law of the United States $\S 401$ (1987). George was a proud elected member of the American Law Institute. I do not recall discussing the Restatement's distinctions with him, although I expect he would have found them helpful. In GP Barton "Foreign Armed Forces: Immunity from Supervisory Jurisdiction", above n 1, at 380, he finessed the distinctions in his writing in this way:

Criminal jurisdiction is exercised whenever the courts of a state take cognizance of an offence against the penal law of that state. This definition excludes the pre-trial activities of the police and other law enforcement agencies of a state in detecting, apprehending, and prosecuting offenders against the penal law. The policeman is an official of the executive, not the judiciary. Thus, a member of a visiting force is subject to the criminal jurisdiction of the local state only when he is liable to be tried in its courts for offences against its penal law.

73 See above $n$ 70. And note the way in which the Model agreement confers a limited power to arrest (enforcement jurisdiction) on the host State, while leaving prescriptive and adjudicative power with the sending State, above n 45. 
agree to have 'foreign' trials (military or otherwise) on its territory. It could, in short, assist with enforcement jurisdiction while prescriptive and adjudicative jurisdiction lay elsewhere.

A further possibility of shared disciplinary jurisdiction arises in respect of the United Nations' own administrative investigations. The organisation having no power of criminal adjudication, such investigations can lead only to employment sanctions, including termination. The Group regarded it as important that there be coordination in such investigations among the relevant organs of the United Nations, the authorities of the host State and the authorities of any other State (such as the State of nationality) that has a potential role in criminal proceedings. States should be encouraged to make provisions in their laws "to facilitate the admission in criminal proceedings of evidence obtained in the host State by the United Nations during the conduct of its administrative investigation." 74

Several features of a possible regime are spelled out in the Draft Convention attached to the Group's report. Article 3 is a definitional provision, setting out the "serious crimes" to which the Convention applies. These are murder; wilfully causing serious injury to body or health; rape and acts of sexual violence; sexual offences involving children; an attempt to commit such crimes; or participation in any capacity such as an accomplice, assistant or instigator in any such crimes. ${ }^{75}$ Article 4 would require a State Party to take such measures as may be necessary to establish jurisdiction over the crimes when: (a) they are committed in the territory of that State, or (b) they are committed by a national of that State. ${ }^{76}$ Jurisdiction may also be established where the crime is committed against a national of the State, or where the crime is committed by a stateless person who

74 Report of Group of Legal Experts, above n 59, at 25.

75 Ibid Annex III Draft convention on the criminal accountability of United Nations officials and experts on mission, art 3, at 29 [Draft Convention]. The list, it will be noticed, is not confined to sex crimes, although they featureprominently. The list will no doubt be amplified as the exercise proceeds to include, for example, sex trafficking, some property offences, money laundering and smuggling of items such as weapons and blood diamonds. A 2011 prosecution in the Democratic Republic of the Congo for trafficking the mineral cassiterite (used in making cell phones) is suggestive. See Associated Press "3 years for UN driver caught trafficking minerals in Congo" The Washington Post (Washington, 25 August 2011). The United Nations "agreed to lift the driver's immunity".

76 At art 4(1). Many members of a mission will be on short term contracts and maintain ties to their home countries. Permanent members of the Secretariat may, however, have spent many years in United Nations service far from their place of nationality. "Home" may be New York, Geneva or Vienna. The nationality tie is necessarily tenuous for an international official, but there does not seem to be much alternative to relying on it for at least some criminal purposes. Perhaps some kind of "residence" jurisdiction can be devised for those sent abroad from headquarters. There are occasional examples of officials in New York being prosecuted in United States Federal Court (for actions taking place at headquarters) upon waiver of immunity by the Secretary-General. See for example, the corruption case, US v Bahel 662 F 3d 610 (2d Cir 2011). Obviously United States legislation would normally be required to achieve such an end. In Bahel, it was perhaps fortuitous that there was United States prescriptive law, triggered by the United States financial contribution to the United Nations, that could be applied. 
has his or her habitual residence in the territory of that State. ${ }^{77}$ More controversially, each party would be required to: ${ }^{78}$

... take such measures as may be necessary to establish its jurisdiction over the crimes set out in article 3

in cases where the alleged offender is present in its territory and it does not extradite that person

pursuant to article 8 to any of the States parties which have established their jurisdiction in accordance with ... the present article.

This is extradite-or-prosecute, or 'fallback universal jurisdiction', ${ }^{79}$ triggered by the presence of the alleged offender in the State in question. There would, however, be no obligation to prosecute unless there was double criminality. ${ }^{80}$ The Group discusses the pros and cons of asserting universal jurisdiction, emphasising the significant concern that such crimes have to the international community, the "gravity" of which "lies in the breach of what is akin to a relationship of trust between the peacekeeper and the members of the community he or she is sent to protect and assist." ${ }^{81}$ Hence the conclusion: ${ }^{82}$

57. Such crimes cannot therefore be regarded as merely ordinary crimes. They do not, on the other hand, necessarily arise to the level of such international crimes as piracy, war crimes or crimes against humanity that attract universal jurisdiction, in the sense of any State being able to assert jurisdiction irrespective of the location of the offender or the nationality of the persons involved.

58. The Group is of the view that the assertion of universal jurisdiction on the basis of an extradite or prosecute regime underpinned by a treaty strikes an appropriate balance between the considerations in the argument and counter-argument set out above. A State on whose territory an alleged offender is found can extradite him or her to the State of nationality or to another State that has established jurisdiction. But if it does not do so, it must refer the case to its competent authorities for the purpose of prosecution under its domestic laws.

77 At art 4(2). This jurisdiction is permissive, not obligatory. A reasonable question is why there should not be jurisdiction over residents in general, not only Stateless residents. Many long-term residents (including international civil servants) have much closer ties to their country of residence than to their country of nationality.

78 At art 4(4). See also art 7 (requiring the exercise of the jurisdiction contained in art 4(4)). This kind of 'custodial state' jurisdiction may make special sense in respect of established international officials with few existing ties to their country of nationality.

79 See RS Clark "Offenses of International Concern: Multilateral State Treaty Practice in the Forty Years Since Nuremberg" (1988) 57 Nordic JIL 49 (discussing series of such treaty provisions beginning with those in conventions on hijacking and other offences against aircraft).

80 Draft Convention, above n 75, art 9.

81 Report of Group of Legal Experts, above n 59, at 16-17.

82 Ibid. 
The Draft Convention also contains provisions fostering extradition, ${ }^{83}$ cooperation, ${ }^{84}$ transfer of criminal proceedings, ${ }^{85}$ and transfer of prisoners. ${ }^{86}$

Overall, the Draft Convention would encourage more States to legislate to provide concurrent prescriptive jurisdiction over the types of crime in question, especially when committed by their nationals. The accompanying efforts to enhance various aspects of enforcement jurisdiction in more than one place would improve the chances of something actually being done.

It is fair to add that the negotiation of the treaty is proceeding at a leisurely pace. The next serious moves are not scheduled until late 2012. ${ }^{87}$

\section{A NEW UNITED NATIONS MODEL MEMORANDUM OF UNDERSTANDING}

Along with the SOFA with the host country, the Secretary-General has customarily formulated a treaty arrangement with the troop-contributing countries setting out the terms of that arrangement. In 1991, the Secretary-General made available what he called a Model agreement between the United Nations and Member States contributing personnel and equipment to United Nations peace-keeping operations (Model Contributor agreement). ${ }^{88}$ In addition to dealing with various financial and administrative measures, the Model Contributor agreement contained several provisions germane to the present discussion. It referred to the Model status of forces agreement for peace-keeping operations, noting that the latter "affirms the international nature" of the operation "as a subsidiary organ of the United Nations and defines the privileges and immunities, rights and facilities, as well as the duties" of the operation and its members. ${ }^{89}$ The Model Contributor agreement emphasises the

83 Draft Convention, above n 75, art 8.

84 At art 10.

85 At art 11.

86 At art 12

87 Criminal accountability of United Nations Officials and experts on mission GA Res 65/20, A/Res/65/20 (2010) at [8] (consideration of issue by working group of Sixth Committee during 67th Session of the General Assembly in 2012).

88 Comprehensive review of the whole question of peacekeeping operations in all their aspects A/46/185 (1991) [Model Contributor agreement].

89 Ibid art 4. 
"exclusively international" nature of the mission and insists that, except on national administrative matters, its members: ${ }^{90}$

... shall not seek or accept instructions in respect of the performance of their duties from any authority

external to the United Nations, nor shall the Government of [Participating State] give such instructions to them.

It adds, in a section headed "Jurisdiction", that allegations of criminal offences and civil liability are to be settled in accordance with the status agreement. ${ }^{91}$ Moreover, the participating State: ${ }^{92}$

... agrees to exercise jurisdiction with respect to crimes or offences that may be committed by its military personnel serving with [the United Nations peace-keeping operation]. [The Participating State] shall keep the Head of Mission informed regarding the outcome of such exercise of jurisdiction.

Subsequent modifications of the detailed arrangements with participating States were published in $1996^{93}$ and 1997. ${ }^{94}$ The 1997 version changed the title of the instrument to "Memorandum of Understanding".

A bold statement made in the 1991 Model Contributor agreement was that "[p]ending the conclusion of such an agreement, the United Nations shall apply the customary principles and practices which are embodied in the status-of-forces agreement."95 I am not certain that the word "customary" used here was deliberately chosen as an assertion that this is a proposition of customary international law or more a softer reference to what is 'usual'. I suspect that George would still have not been convinced: why have an agreement if the customary law gets the same results? ${ }^{96}$ Why has it been the norm to conclude an agreement? But the customary argument has support elsewhere, and perhaps a special case can be made for peacekeepers, as opposed to other visitors, a case based on necessity. In an e-mail responding to my request for a comment on New Zealand practice in respect

90 At art 9. This language echoes art 100 of the Charter of the United Nations concerning the Secretariat.

91 At art 24.

92 At art 25.

93 Reform of the procedures for determining reimbursement to Member States for contingent-owned equipment, Note by the Secretary-General A/50/995 (1996).

94 Reform of the procedures for determining reimbursement to Member States for contingent-owned equipment, Note by the Secretary-General A/51/967 (1997).

95 Model Contributor agreement, above n 88, art 6.

96 See also above n 8 on his methodology. I am speaking here of the existence, vel non, of a customary rule. It will often be advantageous to have an agreement to put under the nose of a recalcitrant host official even if it contains rules that are consistent with custom. 
of its peacekeeping forces, Brigadier Kevin Riordan of the New Zealand Defence Force commented, in light of the experience in East Timor, that: ${ }^{97}$

97 E-mail from Kevin Riordan (New Zealand Defence Force) to the author containing material supplied to Dutch PhD student (23 August 2011). Brigadier Riordan noted that Australia negotiated, by Diplomatic Note on 24 September 1999, what it referred to as a SOFA with Indonesia, purporting to bind all members of the INTERFET force. He continues:

However, as a question of law some troop contributing nations had difficulty with the notion of excluding, by diplomatic process, a legal system [Indonesia's] which they not only did not recognise as having jurisdiction, but which, as a matter of fact, had ceased to exist.

I agree with the nullity of the Indonesian position in East Timor: see RS Clark "Obligations of Third States in the Face of Illegality - Ruminations inspired by the Weeramantry Dissent in the case Concerning East Timor" in A Anghie and G Sturgess (eds) Legal Visions of the 21st Century: Essays in Honour of Judge Christopher Weeramantry (Kluwer Law International, The Hague, 1998) at 631.

Brigadier Riordan noted that "for nearly three years ... UN forces operated in Croatia without the protection of a formal SOFA" before the Croatian authorities agreed to one. For support of general international law as a source of immunity in the host State, see D Fleck "Are Foreign Military Personnel Exempt from International Criminal Jurisdiction under Status of Forces Agreements?" (2003) 1 JICJ 651; JHF van Panhuys "Some Recent Developments of International Law in respect of the Conflicts of Jurisdiction Resulting from the Presence of Foreign Armed Forces in the Territory of a State" (1955) 2 Netherlands ILR 253 at 255-256. For a different position on whether the exclusive jurisdiction of the sending State is a feature of customary law, see R Burke "Status of Forces Deployed on UN Peacekeeping Operations: Jurisdictional Immunity" (2011) 16 JCSL 63 at 96-102; Z Deen-Racsmány "The Amended UN Model Memorandum of Understanding: A New Incentive for States to Discipline and Prosecute Military Members of National Peacekeeping Contingents?" (2011) 16 JCSL 321 at 19 points out that:

In any case, SC resolutions setting up or authorising new operations commonly contain a provision noting that until the conclusion of a mission specific SOFA, the provisions of the Model SOFA shall apply. In the context of non-consensual operations, such resolutions are adopted under Chapter VII of the UN Charter. They are hence capable of creating binding obligations under international law, rendering the question of customary status irrelevant for the present purposes.

"Commonly" does not necessarily mean "invariably". For an example, see The Situation in Liberia SC Res 1509, S/Res/1509 (2003) at [7]:

Requests the Liberian Government to conclude a status-of-force agreement with the SecretaryGeneral within 30 days of adoption of this resolution, and notes that pending the conclusion of such an agreement the model status-of-force agreement dates 9 October 1990 (A/45/594) shall apply provisionally.

For parties to the Rome Statute of the International Criminal Court, a sending State's "exclusive" right to exercise jurisdiction will sometimes be trumped by its obligation (or the host State's obligation?) to hand someone over to the ICC. In Peace and Security in Africa SC Res 1970, S/Res/1970 (2011) at [6] concerning Libya, the Council decided that:

[The] nationals, current or former officials or personnel from a State outside the Libyan Arab Jamahiriya which is not a party to the Rome Statute of the International Criminal Court shall be subject to the exclusive jurisdiction of that State for all alleged acts or omissions arising out of 
It was our view that customary international law relative to peacekeeping operations had now developed to the point that certain principles could be confidently asserted. We considered that these principles apply where forces are lawfully deployed on peace support operations in accordance with the Charter of the United Nations even when no formal Status of Forces Agreement is in place. These were that New Zealand forces participating in operations must:

(1) Refrain from any conduct incompatible with the impartial nature of the mission.

(2) Respect all local laws and regulations.

(3) Respect the religious beliefs and customs of the country.

(4) Have unrestricted freedom of communication.

(5) Have unrestricted freedom of movement

(6) Have privileges and immunities in respect of the importation of supplies and other goods.

(7) Have the right while on duty to wear New Zealand military uniform with any issued accoutrements pertaining to the force.

(8) If apprehended while committing or attempting to commit an offence, be immediately delivered to the nearest representative of the peacekeeping force.

(9) Be subject to the exclusive jurisdiction of the New Zealand national contingent in respect of criminal offences.

In June 2007, the General Assembly's Special Committee on Peacekeeping endorsed the report of its open-ended ad hoc Working Group of Experts recommending to the General Assembly that it request the Secretary-General to incorporate a number of amendments into the Model Memorandum of Understanding (the Revised Memorandum of Understanding). ${ }^{98}$ The amendments include

or related to operations in the Libyan Arab Jamahiriya established or authorised by the Council unless such exclusive jurisdiction has been expressly waived by the State.

Similar provisions can be found in Security Council resolutions going back at least as far as The Situation in Liberia SC Res 1497, S/Res/1497 (2003) concerning Liberia. Note that such paragraphs can be read as a special concession to non-parties to the ICC Statute (especially the United States) and leave parties to the Statute possibly vulnerable in the absence of a further paragraph like that in SC Res 1509 above.

98 Report of the Special Committee on Peacekeeping Operations and its Working Group on the 2007 resumed session (Part III) A/61/19 (2007) Annex (Revised Memorandum of Understanding). See Z Deen-Racsmány, above $n$ 97. Deen-Racsmány accepts that this is an improvement over the previous models but argues that it does not go as far as some of Prince Zeid's suggestions (and others on the table during the discussions). The author notes, for example, that it does not push forward the idea of having on-site courts-martial by contributing States, some of whom do still not exercise extraterritorial jurisdiction. Nor is participation in a peacekeeping operation made contingent on the acceptance of stringent standards of accountability. It is also noted that there had been suggestions to extend the project on accountability of United Nations officials and experts to military contingents. 
references to United Nations standards of conduct, ${ }^{99}$ to training in them by both the government and the organisation itself, ${ }^{100}$ to the responsibility of the commander of the national contingent for the discipline and good order of the contingent, ${ }^{101}$ and to sharing information gathered by the United Nations with national authorities. ${ }^{102}$ The Revised Memorandum of Understanding repeats the basic principle that military members of a mission and any civilian members subject to national military law are subject to the government's exclusive jurisdiction in respect of crimes and offences. ${ }^{103} \mathrm{It}$ adds that "[t]he Government assures the United Nations that it shall exercise such jurisdiction with respect to such crimes or offences."104 Moreover, the government undertakes to exercise disciplinary jurisdiction over misconduct falling short of crimes or offences. ${ }^{105}$ The obligation to take prosecutorial action is spelled out further in art 7 sexiens, headed "Accountability":

1. If either a United Nations investigation or an investigation conducted by the competent authorities of the Government concludes that suspicions of misconduct by any member of the Government's national contingent are well founded, the Government shall ensure that the case is forwarded to its appropriate authorities for due action. The Government agrees that those authorities shall take their decision in the same manner as they would in respect of any other offence or disciplinary infraction of a similar nature under its laws or relevant disciplinary code. The Government agrees to notify the Secretary-General of progress on a regular basis, including the outcome of the case.

This new formulation is consistent with other modern extradite-or-prosecute obligations under which the obligation is not necessarily to prosecute but to make a good faith determination of the situation, including the likelihood of success, and to proceed accordingly. What is crucial, however, is that, if immunity is to be granted in the host State, the sending State must be able and willing to contemplate prosecution so that there shall be no impunity - a situation that is still all too often the case.

\section{CONCLUSION: MORE THOUGHTS ATTRIBUTED FONDLY TO GEORGE}

Immunity and jurisdiction are inextricably intertwined. Immunities of members of United Nations peacekeeping operations are largely the product of treaty practice, where one of the parties is the United Nations and the other is either a mission-receiving or a troop-providing country. Good

99 Revised Memorandum of Understanding, ibid at amended arts 3 and 7 bis.

100 At art 7 bis.

101 At art 7 ter.

102 At art 7 quarter.

103 At art 7 quinquiens (1).

104 Ibid.

105 At art 7 quinquiens (2). 
practice suggests that if a status treaty is not adopted immediately, an appropriate provision should be included invariably in a Security Council resolution applying the Model SOFA on an interim basis to all contributors. There is a case to be made, although it is not overwhelming, that at least in respect of peacekeepers, there is now a customary rule supporting immunity from the criminal jurisdiction of the host State. But it is more satisfactory to be able to rely on a Security Council resolution or a SOFA for that purpose.

In the case of soldiers provided for the mission, those troops, while under general control of the organisation, also remain part of a national body and are thus clearly amenable to national jurisdiction, military or civil. The main problem here is that not all troop providers have made adequate provision in their law and practice for exercising prescriptive and adjudicative jurisdiction either on home soil or in situ at the place of the operation. The first line of attack is obviously to encourage the development of the necessary legislation and the creation of appropriate prosecutorial capacity. A court-martial at the scene of the crime is likely to carry more gravitas with the local population than one far from the scene. It is also the place witnesses are likely to be located. It is therefore to be encouraged. Since sending State jurisdiction will still not always happen, more thought needs to be given to the possibility of waiving, when appropriate, the absolute denial of jurisdiction in the territorial State. Concurrent jurisdiction may have a role to play here.

In the case of non-military participants, who are normally under the aegis of the SecretaryGeneral as some kind of international official, the normal functional immunity, accompanied by the power of the Secretary-General (or his representative) to determine whether the action took place in the course of official duty and whether any immunity should be waived, means that there is some possibility of prosecution in the host State. It is important, as the Group of Legal Experts suggested, that there be capacity building in host States so that prosecutions may be carried out there. Beyond that, there is need for conclusion of the jurisdictional treaty that will make it possible for the State of nationality and probably third States to carry out proceedings, bearing in mind that the best efforts at capacity-building may not always bear fruit in time. Those persons who are true international officials who are no longer associated with their State of origin are obvious candidates for the exercise of adjudicative jurisdiction perhaps even on State-of-Residence or a universal theory. It is important to remember that adjudicative power can be separated from prosecutorial power and also from carrying out imprisonment. In the longer term, when the United Nations has no longer to rely on ad hoc arrangements, the whole idea of a treaty-based United Nations court system (perhaps with imprisonment a national undertaking) ${ }^{106}$ must be on the agenda.

106 I have in mind something like the agreements that the International Criminal Court enters into with States Parties pursuant to art 103 of the Rome Statute of the International Criminal Court 2187 UNTS 3 (opened for signature 17 July 1998, entered into force 1 July 2002) to enforce sentences of imprisonment. 
